\title{
Effects of Contraceptive Use on Productivity of Women Labor at PT. X Makassar Industrial Area
}

\section{Dampak Penggunaan Alat Kontrasepsi terhadap Produktivitas Tenaga Kerja Perempuan di Kawasan Industri PT. X Makassar}

\author{
Masni*, Andi Misnawati*, Darmawansyah**
}

*Graduate Programe, Reproductive and Family Health Concentration, Faculty of Public Health, Hasanuddin University, Makassar, Indonesia,**Gaduate Programe, Health Administration and Policy Concentration, Faculty of Public Health, Hasanuddin University, Makassar, Indonesia

\begin{abstract}
Work productivity is potential on the survival of a company. The use of contraceptives may affect the physiology of every woman, so it can affect daily activities and resulted in labor productivity. The aim of this study was to determine the contraceptive use effect on labor woman productivity by controlling with age, education and work motivation. Study with cross sectional design involved 71 married women workers of PT. X Makassar who had got married. Data were found by interview using questionnaire on May to June 2015, then analyzed using univariate, bivariate and multivariate analysis. The results of the study indicate that, there was an effect of contraceptive use on woman labor productivity after controlling for variables as age $(p$ value $=0.011)$, education $(p$ value $=$ 0.022 ) and work motivation ( $p$ value $=0.028$ ). Withouth being controlled by those variables, a significant result showing an effect of contraceptive use on work productivity was also found ( $p$ value $<0.05$ ). The results of multivariable analysis indicate that there were two variables which consistenly affected the productivity, namely work motivation ( $p$ value $=0.010$ ) and contraceptive use ( $p$ value $=0.010)$. In conclusion, there is an effect of contraceptive use on woman labor productivity.
\end{abstract}

Keywords: Contraceptive use, women laborers, work motivation, work productivity

\begin{abstract}
Abstrak pat pengaruh penggunaan alat kontrasepsi terhadap produktivitas kerja.

How to Cite: Masni, Misnawati A, Darmawansyah. Effects of contraceptive use on productivity of women labor at PT. Bomar Makassar. Kesmas: National Public Health Journal. 2017; 12 (1): 43-8. (doi:10.21109/kesmas.v12i1.1419)
\end{abstract}

Produktivitas kerja potensial pada kelangsungan hidup perusahaan. Penggunaan kontrasepsi dapat memengaruhi fisiologi setiap perempuan, sehingga dapat memengaruhi aktivitas sehari-hari dan akan berdampak terhadap produktivitas tenaga kerja. Penelitian ini bertujuan untuk mengetahui pengaruh penggunaan alat kontrasepsi terhadap produktivitas tenaga kerja perempuan dengan mengontrol usia, pendidikan dan motivasi kerja. Penelitian dengan rancangan potong lintang melibatkan 71 pekerja perempuan PT X Makassar yang telah menikah. Pengumpulan data dilakukan dengan wawancara menggunakan kuesioner pada bulan Mei sampai Juni 2015, kemudian dianalisis secara univariat, bivariat, dan multivariat. Hasil penelitian menunjukkan bahwa terdapat pengaruh penggunaan alat kontrasepsi terhadap produktivitas kerja setelah dikontrol dengan variabel usia (nilai $p=0,011$ ), pendidikan (nilai $p=0,022$ ) dan motivasi kerja (nilai $p=0,028$ ). Tanpa dikontrol dengan variabel tersebut, juga terdapat hasil yang signifikan yang menunjukkan dampak penggunaan alat kontrasepsi terhadap produktivitas kerja (nilai $p<0,05$ ). Hasil analisis multivariat menunjukkan bahwa terdapat dua variabel yang konsisten memberikan pengaruh terhadap produktivitas kerja yaitu motivasi kerja (nilai $p=0,010$ ) dan penggunaan alat kontrasepsi (nilai $p=0,010$ ). Dapat disimpulkan bahwa terda-

Kata kunci: Penggunaan kontrasepsi, tenaga kerja perempuan, motivasi kerja, produktivitas kerja

Correspondence: Masni, Reproductive and Family Health Concentration, Faculty of Public Health, Hasanuddin University, Perintis Kemerdekaan Street Km 10, Makassar, Indonesia 90245, Phone: +62411585658, e-mail: masnimappajanci@rocketmail.com

Received: February $10^{\text {th }} 2017$

Revised: August $4^{\text {th }} 2017$

Accepted: August $4^{\text {th }} 2017$ 


\section{Introduction}

Family Planning Program in Indonesia has been recognized nationally and internationally as one of the programs that have succeeded in reducing the fertility rate significantly. This can be seen from the total fertility rate (TFR) of Indonesia that there was a decrease from 3 in 1991 to 2.6 in $2012 .{ }^{1}$ One of the problems in the management of family planning programs is the use of contraceptives for women workers, especially those working for the benefit of the production of goods at various companies. Women who worked at certain companies are required to work actively equal to man labor, but the woman labor force is highly dependent on the biological characteristics, such as menstruation, pregnancy, childbirth and breastfeeding, which need leave during a specific time period. Results of study by Frost et al., ${ }^{2}$ and Bailey et al., 3 show that women who use contraceptives can increase their work productivity.

The importance of such leave is to maintain the health of women workers, as well as maintaining the level of employment potential productivity on the survival of the company. It also will have an impact on population growth rates, given the amount of labor that is high enough who work at the company. Contraceptive use has some impacts, such as a tool to control the number of children and birth spacing. Increasing contraceptive use from time to time will help transform and reshape women's expectations about educational opportunities, career, and their role at home and workplace. However, the use of contraceptives can affect the physiology of each woman, so it can affect daily activities. It is also found by the study that there are several side effects that can be felt in the use of contraceptives, including bleeding and changes in menstrual patterns, changes in mood that impact on the activities undertaken by women and can affect the daily activities of women. ${ }^{4}$ To avoid the side effects, each couple of childbearing age use contraceptives before first birth control contraceptive consult a suitable health care workers. Use of contraceptives is a form of health behaviors, especially in women. Many factors influence women in the use of contraceptives. Green in Notoatmodjo analyzed the human behavior of soundness. The behavior is determined or formed from three factors that are predisposing factors which embodied in the characteristics, knowledge, attitudes, beliefs, to conviction, values, etc; supporting factors (enabling factors), which manifested itself in the social environment, the availability or unavailability of the facility or health care facilities; and the driving factor (reinforcing factors) manifested in the support of those closest, support the attitudes and behaviors of health workers in providing health education, which is a reference group of people's behaviour. $^{5}$

Shows the level of labor productivity in the employ- ee's ability to achieve results (output), especially in terms of quantity. This means that work productivity can be interpreted as the result of concrete products produced by individuals or groups, during a certain time in a work process. In this case, the higher the resulting product in a short time is considered as the high level of work productivity. ${ }^{6}$ Based on the background outlined above, this study was conducted to determine the effect of contraceptive use on women labor productivity by controlling the variables of age, education and work motivation.

\section{Method}

The study was cross-sectionally conducted at PT. X which is located in industrial area of Makassar. The population of this study was all married women workers at PT. X Makassar. A sample of 71 respondents were selected overall (exhaustive sampling), married women workers at PT. X Makassar and willing to be respondent in this study. Data were collected from May to June 2015. The primary data were obtained through direct interviews using validated questionnaire which had been prepared in advance in accordance with the purpose of study. Then secondary data were obtained from institutions associated with study such as the PT. X Makassar.

For data analysis, univariate analysis was applied to determine the distribution of all single variables including the common characteristics of respondents and presented in a frequency distribution table, bivariate analysis to determine the effect of independent variables on the dependent variable based on the control variables, and multivariate analysis to determine how much influence of both the independent variables and controls on the dependent variable.

\section{Results}

Respondent characteristics include age, education level, length of employment, contraceptive use. Age of respondents was mostly 26-30 years (39.4\%). Most of the last education level was high school $(36.6 \%)$ and most of the respondents worked long, $1-<5$ years $(31.0 \%)$. Table 1 presents that $73.2 \%$ respondents used contraceptives and most respondents (33.8\%) used injection contraceptive.

The results of bivariate analysis (Table 2) found that women workers who used contraceptives were more productive than women workers who did not use contraceptives. The statistical test showed a significant result ( $p$ value $=0.001$ ) meaning that there was an effect of contraceptive use on work productivity.

The effect of contraceptive use on labor productivity by controlling for variables age, education and work motivation can be seen in Table 3. By controlling with age, for age category $\leq 30$ years such as regulate births phase, women workers who used contraceptives more produc- 
tive than women workers who did not use contraceptives, but the results of statistical analysis found no effect of contraceptives use on work productivity $(\mathrm{p}$ value $=$ 0.140 ). Meanwhile, at the age group $>30$ years which ended the phase of birth, women workers who used contraceptives were more productive than those who did not, with the statistical test which found an effect of contraceptives use with labor productivity ( $\mathrm{p}$ value $=0.05$ ) By controlling with variable education, in category less and enough, women workers who use contraceptives more productive than women workers who are not using contraception. The results of statistical test showed that there was an effect of contraceptive use on work productivity ( $\mathrm{p}$ value $<0.05$ ). By controlling with work motivation, in category less and enough, women workers who used contraceptives were more productive than women workers who did not. The statistical test results found an effect of contraceptive use on work productivity with $\mathrm{p}$ value $<0.05$ (Table 3 ).

The results of multivariate analysis showed that each control variable and independent variable were entered simultaneously. There were two variables that affected the productivity of labor, namely work motivation ( $\mathrm{p}$ value $=0.010)$ and the use of contraceptives ( $\mathrm{p}$ value $=$ 0.010) (Table 4).

\section{Discussion}

Efforts to increase the contraceptive use are performed by achieving development pertaining to the popu-
Table 1. Characteristics of Respondents at PT. X Makassar, 2015

\begin{tabular}{llrr}
\hline Characteristics & Category & n & $\%$ \\
\hline \multirow{2}{*}{ Age (years) } & $\leq 25$ & 11 & 15.5 \\
& $26-30$ & 28 & 39.4 \\
& $31-35$ & 17 & 23.9 \\
& $36-40$ & 10 & 14.1 \\
Education & $>40$ & 5 & 7.0 \\
& Junior high school & 24 & 33.8 \\
Length of working (years) & High school & 26 & 36.6 \\
& Undergraduate & 21 & 29.6 \\
& $<1$ & 19 & 26.8 \\
Contraceptive use & $1-<5$ & 22 & 31.0 \\
Kinds of contraceptive use & $5-10$ & 18 & 25.4 \\
& $>10$ & 12 & 16.9 \\
& Yes & 52 & 73.2 \\
& No & 19 & 26.8 \\
& Not use & 19 & 26.8 \\
& Pil & 22 & 31.0 \\
& Injection 1 month & 3 & 4.2 \\
& Injection 3 months & 21 & 29.6 \\
& Implant & 2 & 2.8 \\
& Intra uterine divice (IUD) & 4 & 5.6
\end{tabular}

Table 2. The Effect of Contraceptive Use on Labor Productivity at PT. X Makassar, 2015

\begin{tabular}{|c|c|c|c|c|c|c|c|}
\hline \multirow{3}{*}{ Contraceptive Use } & \multicolumn{4}{|c|}{ Work Productivity } & \multirow[b]{2}{*}{ Total } & \multirow{2}{*}{\multicolumn{2}{|c|}{ p Value }} \\
\hline & \multicolumn{2}{|c|}{ Productive } & \multicolumn{2}{|c|}{ Unproductive } & & & \\
\hline & $\mathbf{n}$ & $\%$ & $\mathbf{n}$ & $\%$ & $\mathbf{n}$ & $\%$ & \\
\hline Yes & 39 & 75.0 & 13 & 25.0 & 52 & 100 & 0.001 \\
\hline No & 5 & 26.3 & 14 & 73.7 & 19 & 100 & \\
\hline
\end{tabular}

Table 3. The Effect of Contraceptive Use on Labor Productivity by Controlling with Variables Age, Education and Motivation at PT. X Makassar, 2015

\begin{tabular}{|c|c|c|c|c|c|c|c|c|}
\hline \multirow{3}{*}{ Contraceptive Use } & & \multicolumn{4}{|c|}{ Productivity } & & & \multirow{3}{*}{ p Value } \\
\hline & & \multicolumn{2}{|c|}{ Productive } & \multicolumn{2}{|c|}{ Unproductive } & \multicolumn{2}{|c|}{ Total } & \\
\hline & & $\mathbf{n}$ & $\%$ & $\mathbf{n}$ & $\%$ & $\mathbf{n}$ & $\%$ & \\
\hline \multicolumn{9}{|l|}{ Age (years) } \\
\hline \multirow[t]{3}{*}{$\leq 30$} & Yes & 25 & 80.6 & 6 & 19.4 & 31 & 100 & \\
\hline & No & 3 & 50.0 & 3 & 50.0 & 6 & 100 & 0.140 \\
\hline & Total & 28 & 75.7 & 9 & 24.3 & 37 & 100 & \\
\hline \multirow[t]{3}{*}{$>30$} & Yes & 14 & 66.7 & 7 & 33.3 & 21 & 100 & \\
\hline & No & 2 & 15.4 & 11 & 84.6 & 13 & 100 & 0.005 \\
\hline & Total & 16 & 47.1 & 18 & 52.9 & 34 & 100 & \\
\hline \multicolumn{9}{|l|}{ Education } \\
\hline \multirow[t]{3}{*}{ Enough } & Yes & 31 & 79.5 & 8 & 20.5 & 39 & 100 & \\
\hline & No & 4 & 40.0 & 6 & 60.0 & 10 & 100 & 0.022 \\
\hline & Total & 35 & 71.4 & 14 & 28.6 & 49 & 100 & \\
\hline \multirow[t]{3}{*}{ Less } & Yes & 8 & 61.5 & 5 & 38.5 & 13 & 100 & \\
\hline & No & 1 & 11.1 & 8 & 88.9 & 9 & 100 & 0.031 \\
\hline & Total & 9 & 40.9 & 13 & 59.1 & 22 & 100 & \\
\hline \multicolumn{9}{|l|}{ Work motivation } \\
\hline \multirow[t]{3}{*}{ Enough } & Yes & 30 & 83.3 & 6 & 16.7 & 36 & 100 & \\
\hline & No & 4 & 44.4 & 5 & 55.6 & 9 & 100 & 0.028 \\
\hline & Total & 34 & 75.6 & 11 & 24.4 & 45 & 100 & \\
\hline \multirow[t]{3}{*}{ Less } & Yes & 9 & 56.2 & 7 & 43.8 & 16 & 100 & \\
\hline & No & 1 & 10.0 & 9 & 90.0 & 10 & 100 & 0.037 \\
\hline & Total & 10 & 38.5 & 16 & 61.5 & 26 & 100 & \\
\hline
\end{tabular}


Table 4. The Results of Multivariable Analysis

\begin{tabular}{lcccccr}
\hline Variable & B & Wald & p Value & OR & \multicolumn{2}{c}{$\mathbf{9 5 \% \mathbf { C l }}$} \\
\cline { 5 - 7 } & & & & & Lower & Upper \\
\hline Age & 1.064 & 2.948 & 0.086 & 2.897 & 0.860 & 9.752 \\
Education & 0.922 & 2.118 & 0.146 & 2.513 & 0.726 & 8.697 \\
Work motivation & 1.602 & 6.629 & 0.010 & 4.962 & 1.466 & 16.795 \\
Contraceptive use & 1.771 & 6.679 & 0.010 & 5.874 & 1.534 & 22.494 \\
\hline
\end{tabular}

lation and actualize a happy and small prosperous family. Quality family is a prosperous, healthy, advanced, independent, responsible and harmonious family with ideal number of children and looking forward. The purpose of Family Planning Program is to actualize the harmony and balance of population policy in order to encourage the implementation of national and regional development pertaining to the population, foster partnerships, the increased prosperity, independence and resilience family. ${ }^{7}$ The result of study which was conducted in five countries by Johnson et al., 8 reported that the greatest awareness of contraceptive use today is for contraceptive pills, with varying awareness, but awareness for the use of non-hormonal contraceptive method is still low. Study by Bailey et al., ${ }^{3}$ in the United States demonstrates that the use of contraceptives before the age of 21 years in women workers can make the acceleration in the investment of the labor market women, where women workers have greater opportunities to work full time which means increasing work productivity. The results obtained in this study indicate that the use of contraceptives affect the productivity of labor in line with the results of Fross et al., ${ }^{9}$ study that, women have a variety of benefits from the use of contraceptives, among others, allowing them to have experience improvement in social and economic condition, have a chance to win a higher education and to increase labor force participation, which in turn can increase work productivity.

Age is one factor associated with a person's behavior in the use of contraceptives. Age also can be an indicator of a woman's biological maturity, especially in terms of fertility rates. Age of 15-49 years is a woman's reproductive years, since the age of 15 years is considered to have started to be in the reproductive years and the age of 50 years is considered to have passed the reproductive period (menopause). Results of study by Herawati and Sasana, 10 found that age workforce can determine success in doing a job, both physical and non-physical, as well as productive period of someone, but the results of study by Emerole, ${ }^{11}$ showed that gender, age, monthly income, the number of working days in a month, types of awards received simultaneously give a significant negative contribution to the productivity.

This study results showed that there was no effect of age $\leq 30$ years which regulate phase of birth using contraceptives to the work productivity. Labor worker aged $>30$ years had a long reproductive period, so that they would set the reproductive life. To set the reproductive life, women workers will be looking for effective contraception and have a low failure rate and long term. This study is not in line with the results of study by Puspawibawa et al., 12 finding that age is not related to the use of contraceptive implant. Similar to study by Unumeri et al., 13 in Nigeria, found the age of 30-34 years have a tendency to use contraceptives 3.5 times compared to other age group.

Education is one of factors that can influence a change in attitude or behavior of a person. Education related to the transmission of knowledge, attitudes, beliefs, and skills. The higher a person's education, the better the level of their knowledge, so that the information obtained better to change the way a person against something. ${ }^{5}$ The study result of Putri, ${ }^{14}$ showed that gender, education, work experience give a significant positive effect on productivity. In general, women workers who have formal or informal education have a wider insight. The high awareness of the importance of productivity would encourage the employment of women who undertake productive actions, as is the case with the involvement and participation of the activity program of family planning, the program is aimed for space pregnancy, limiting the number of children, set the spacing between children, which is indirectly play an important role to the improvement of its performance. ${ }^{15}$

The results of this study showed that there was an effect of contraceptive use on work productivity by education level. This study is in line with the study results by Amos, ${ }^{16}$ in Nigeria which found that the level of education is a risk factor for contraceptive use. Women who do not have formal education have a risk 7.4 times to not use contraceptives than those who have a formal education. Women with a good education would be more receptive to innovative behavior than the low educated.

Results of other studies have shown that contraceptive use is determined by the education, the better the education of women, more women used contraceptives. Nishtar et al., 17 found that with a good education, knowledge of contraception would also be good, so that 
contraceptive use will increase. Results of study by Anasel and Mlinga, 18 in Tanzania found that female education is a determinant of contraceptive usage. This is similar to the study results of Al-Balushi et al., ${ }^{19}$ in Oman and study by Moshena et al.,20 in Bangladesh which found that education is a significant factor to the contraseptives use, but all of these results were not in line with Walvekar, ${ }^{21}$ study result which found no association between education of spouses with contraceptive use.

Motivation is also one important factor in determining a choice in the use of contraceptives. Motivation is the encouragement of a person who causes the person to perform certain activities in order to achieve the goal. Sudarti et al., ${ }^{7}$ found that providing motivation through counseling programs aimed for providing information that is expected to increase knowledge on couples of childbearing age, causing the interest to become family planning acceptors and ultimately decided to participate in the family planning program. Results of this study showed that there was an effect of contraceptive use on work productivity based on work motivation. This is in line with the results of study conducted by Speizer et al.,22 which found that the consistent motivation is necessary for an acceptor for the sustainable use of contraceptives, as well as the results of the study by Ryan et al., 23 that the social activity and motivation regarding contraception is an important predictor of contraceptive use and different outcomes based on sex. Results of study Setyaningsih et al., ${ }^{24}$ stated that the family planning service embodied principles of industrial relations to achieve the welfare of workers and improvement of productivity of the company, so that it contained various regulations concerning the rights and obligations of workers and companies that are practice guidelines for creating protection of health and safety, ideally any company employing workers have family planning services.

\section{Conclusion}

Based on the results of this study, it can be concluded that without controlling with variables age, education, and motivation, there is the effect of contraceptive use on work productivity ( $\mathrm{p}$ value $=0.001$ ). Then by controlling with variables age, education and motivation, there is still the significant effect, except for age less then 30 years.

\section{Recommendation}

Several suggestions that can be submitted is the need of increased understanding of women in reproductive age about goal of family planning for the establishment of Small Family Happy and Prosperous Norm, so that the use of contraceptives is not only understood as an attempt to limit the number of children that is already many. Then it is needed to increase the counseling to every company or workplace on family planning, not on- ly about contraception but also how the formation of a quality and prosperous family that is planning the ideal family size for women workers. The last is the need to provide family planning counseling services by each company for women workers.

\section{References}

1. USAID, BPS, BKKBN, and Ministry of Health. Indonesian Demographic and Health Survey. Jakarta: USAID, BPS, BKKBN, Ministry of Health and ICF International; 2012.

2. Frost JJ, Darroch JE. Factors associated with contraceptive choice and inconsistent method use. PubMed Journals National Center for Biotechnology Information (NCBI) of Perspectives on Sexual and Reproductive Health. 2008; 40(2): 94-104.

3. Bailey MJ, Harsbein B, Miller AR. The opt in revolution? contraception and the gender gap in Wages. American Economic Journal: Applied Economics. 2012; 4(3): 225-54.

4. Tolley E, Loza S, Kafafi L, Cummings S. The impact of menstrual side effects on contraceptive discontinuation: findings from a longitudinal study in Cairo, Egypt. PubMed Journals National Center for Biotechnology Information (NCBI) of International Family Planning Perspectives. 2005; 31(1): 15-23.

5. Notoatmodjo S. Ilmu kesehatan masyarakat prinsip-prinsip dasar. Jakarta: Rineka Cipta; 2003.

6. Anoraga P. Work psychology. Jakarta: Rineka Cipta; 2002.

7. Sudarti K, Prasetyaningtyas P. Peningkatan minat dan keputusan berpartisipasi akseptor KB. Jurnal Dinamika Manajemen [Online Journal] 2011 [cited 27 December 2016]; 2(2): 130-8. Available from: http://download.portalgaruda.org/article.php? article $=135515 \& \mathrm{val}=56$ 49.

8. Johnson S, Pion C, Jennings V. Current methods and attitudes of women towards contraception in Europe and America. Journal of Reproductive Health [Online Journal]. 2013 [23 December 2016]; 10(7): 1-9 . Available at: https://preview-reproductive-health-journal.biomedcentral.com/articles/10.1186/1742-4755-10-7.

9. Frost JJ, Linberg LD. Reasons for using contraception: perspectives of us women seeking care at specialized family planning clinics. Journal of Contraception [Online Journal]. 2013 [cited at 23 December 2016]; 87(4): 465-72. Available from: http://www.contraceptionjournal.org/article/S0010-7824\%2812\%2900739-1/abstract

10. Herawati N, Sasana H. The analysis of the effect of education, work experience, sex, rewards and age to the productivity in shuttle cock industry Tegal City [Thesis]. Semarang: Faculty of Economic and Business Diponegoro University; 2013.

11. Emerole OB, Okpara M. Effect of non-monetary rewards on productivity of employees among selected government parastatals in Abia State Nigeria. Journal of Bussiness and Management. 2015; 17 (2) Ver. IV: 0611.

12. Puspawibawa M, Novianti S, Hidayanti L. Faktor ibu yang berhubungan dengan penggunaan implant (studi akseptor KB Desa Anjarsari Kecamatan Leuwisari Kabupate Tasikmalaya) [Skripsi]. Tasikmalaya: Fakultas Kesehatan Masyarakat Universitas Siliwangi; 2014.

13. Unumeri G, Ishaku S, Ahonsi B, Oginni A. Contraceptive use and its socio-economic determinants among women in North-East and North- 
West Regions of Nigeria: a comparative analysis. African Population Studies (APS) [Online Journal]. 2015 [Open access 21 December 2016]; 29(2): 1851-66. Available at: http://aps.journals.ac.za/pub/article/download/757/585.

14. Putri HR. The effect of knowledge, work experience and sex to the work productivity of labor at Production Departemen CV. Karunia Abadi Wonosobo. Jurnal Pendidikan dan Ekonomi Universitas Negeri Yogyakarta. 2016; 5(4): 292-300.

15. Mahendra AD. Analysis the effect of education, wages, gender, age and experience work against labor productivity (study in the small industries tempe in Semarang [Thesis]. Semarang: Faculty of Economic and Business Diponegoro University; 2014.

16. Amos O. Determinnats of contraceptive usage: lessons from women in Osun State, Nigeria. Journal of Humanities and Social Sciences. 2007; 1(2): 1-4.

17. Nishtar NA, Sami N, Alim S, Pradhan N, Husnain FU. Determinants of contraceptive use amongst youth: an explanatory study with family planning service providers in Karachi Pakistan. Global Journal of Health Sciences. 2013; 5(3): 1-8.

18. Anasel MG, Mlinga UJ. Determinants of contraceptive use among married women in Tanzania. Demographic and Health Surveys in Africa of African Population Studies. 2014; 28 (2): 978-88.

19. Al-Balushi MS, Ahmad MS, Islam MM, Khan MHR. Determinants of contraceptive use in Oman. Far East Journal of Theoretical Statistics. 2015; 50 (1): 51-64.

20. Moshena M, Kamal N. Determinants of contraceptive use in Bangladesh. Ibrahim Medical College Journal [Online Journal]. 2014 [cited 22 December 2016]; 8(2): 34-40. Available from: http://www.banglajol.info/index.php/IMCJ/article/view/26676/178

21. Walvekar PR. Determinants of contraceptive use among married women residing in rural areas of Belgaum. Journal of Medical and Allied Sciences. 2012; 2(1): 7-11.

22. Speizer IS, Irani L, O’Fallon JB, Levy J. Inconsistent fertility motivations and contraceptive use behaviors among women in Honduras. Journal of Reproductive Health [Online Journal]. 2009 [cited 22 December 2016] ; 6: 19: 1-10. Available from: https://reproductive-health-journal.biomedcentral.com/track/pdf/10.1186/1742-4755-6-19?site=reproductive-health-journal.biomedcentral.com.

23. Ryan S, Franzetta K, Manlove J. Knowledge, perception, and motivation for contraception: influence on teens contraceptive consistency. SAGE Journal Publication [Online Journal]. 2007 [cited 23 December 2016]; 39(2): 182-208. Available at: http://journals.sagepub.com.

24. Setyaningsih Y, Purnami CT, Mahmudah MA. The relationship between hormonal contraception, knowledge with attitudes about female workers menstruation leave at PT. Nyonya Meneer Semarang. Journal of Health Promotion Indonesia. 2008; 3(2): 115-9. 